\title{
Пространственно-временные особенности накопления тяжелых металлов в организмах рыб водоемов Евро-Арктического региона
}

\author{
Терентьев П.М. \\ Институт проблем промышленной экологии Севера КНЦ РАН, Anamumbl,p_terentjev@inep.ksc.ru
}

Аннотация. В статье приводятся результаты многолетних исследований по изучению особенностей накопления ряда тяжелых металлов (ТМ) в организмах рыб озер Евро-Арктической зоны РФ, испытывающих долговременное аэротехногенное воздействие. Показано, что уровни антропогенной нагрузки на водоемы на протяжении последних десятилетий остаются без значительных улучшений. Кроме того, отмечена тенденция к росту содержания некоторых ТМ в организмах рыб в настоящее время. Отмечено, что среди рассматриваемых ТМ наиболее высокие уровни накопления наблюдаются в органах и тканях сига, характеризующегося преимущественно бентосным типом питания. Практически во всех рассматриваемых водоемах зарегистрирована высокая вариабельность содержаний ТМ в пределах одного вида. Также установлено, что интенсивность антропогенной нагрузки не имеет четко выраженного градиентного характера, поскольку даже в наиболее удаленных водных системах содержания ТМ в тканях рыб были сопоставимы с таковыми в водоемах, подверженных непосредственному воздействию локального предприятия медно-никелевого производства.

Ключевые слова: тяжелые металлы; рыбы; аккумуляция; антропогенное загрязнение, Арктика.

\section{Spatial and temporal particularities of heavy metals accumulation in fishes of Euro-Arctic reservoirs}

\author{
Terentjev P.M \\ Institute of North Industrial Ecology Problems KSC RAS, Apatity,p_terentjev@inep.ksc.ru
}

\begin{abstract}
The article presents results of long-term research study of particular features of heavy metals (HM) accumulation in organisms of fish inhabiting the Euro-Arctic lakes of the Russian Federation, exposed to different levels of aerotechnogenic impact. It is shown that levels of anthropogenic load on reservoirs over the last decades remain without significant improvements. In addition, there is currently a tendency of increasing content of some HMs in fish organisms. It is noted that among the considered HMs, the highest levels of accumulation are observed in organs and tissues of whitefish, which is characterized mainly by the benthic type of nutrition. Practically in all the water bodies under consideration, a high variability in the HMs content within one species is registered. It has been also established that the intensity of the anthropogenic load does not have a clearly defined gradient character. It is shown that in the most remote water systems, the HMs content in fish tissues is comparable to those in reservoirs exposed to the direct impact of a local enterprises of copper-nickel production.
\end{abstract}

Key words: heavy metals; fishes; accumulation; anthropogenic pollution; Arctic.

\section{Введение}

Приоритетными загрязняющими веществами крайнего северо-запада России и сопредельных территорий северной Норвегии и Финляндии являются тяжелые металлы (ТМ) и кислотообразующие соединения. Основными источники аэротехногенного загрязнения на территории Мурманской области являются площадки Кольской ГМК ПАО ГМК «Норильский никель» (Никельская и Мончегорская), автотранспорт и предприятия топливно-энергетического комплекса. Их деятельность сопряжена с поступлением огромных количеств пыли, окислов серы и ТМ в пресноводные экосистемы благодаря процессам атмосферного переноса. В районах деятельности промышленных предприятий, в частности предприятий цветной металлургии, отмечаются повышенные содержания ТМ $(\mathrm{Ni}, \mathrm{Cu}, \mathrm{Co}, \mathrm{Cd}, \mathrm{Cr}, \mathrm{Hg}$ и др.) в водах, снежном покрове, растительности, поверхностных слоях донных отложений и гидробионтах (Даувальтер, Кашулин, 2018; Терентьев, Кашулин, 2010; Boquete et al., 2014; Dauvalter, Kashulin, 2018; Fu et al., 2014; Kashulin et al., 2011). Изучение влияния ТМ на организмы, как правило, проводятся в ходе экспериментальной оценки реакции на острый стресс. Значительно меньше данных существует о подобных процессах для организмов, испытывающих хроническое (сублетальное) воздействие (Hansen et al., 2002). Целью данной работы является изучение 
пространственно временных особенностей накопления ТМ в организмах рыб разных видов в условиях градиентной нагрузки.

\section{Результаты и обсуждение}

Исследования по оценке уровней накопления ТМ в организмах рыб проводились на озерах приграничного района Мурманской области (рис. 1). Для ряда озер (Шуонияур, Виртуовошъяур и Кочеяур) имеются данные о ТМ за продолжительный период. Особое внимание было уделено приоритетным загрязняющим веществам, связанным с деятельностью Никельской площадки Кольской ГМК - никелю и меди. Также были проанализированы особенности накопления в организмах рыб цинка. Концентрации металлов в органах рыб оценивались в мкг/г сух. веса.

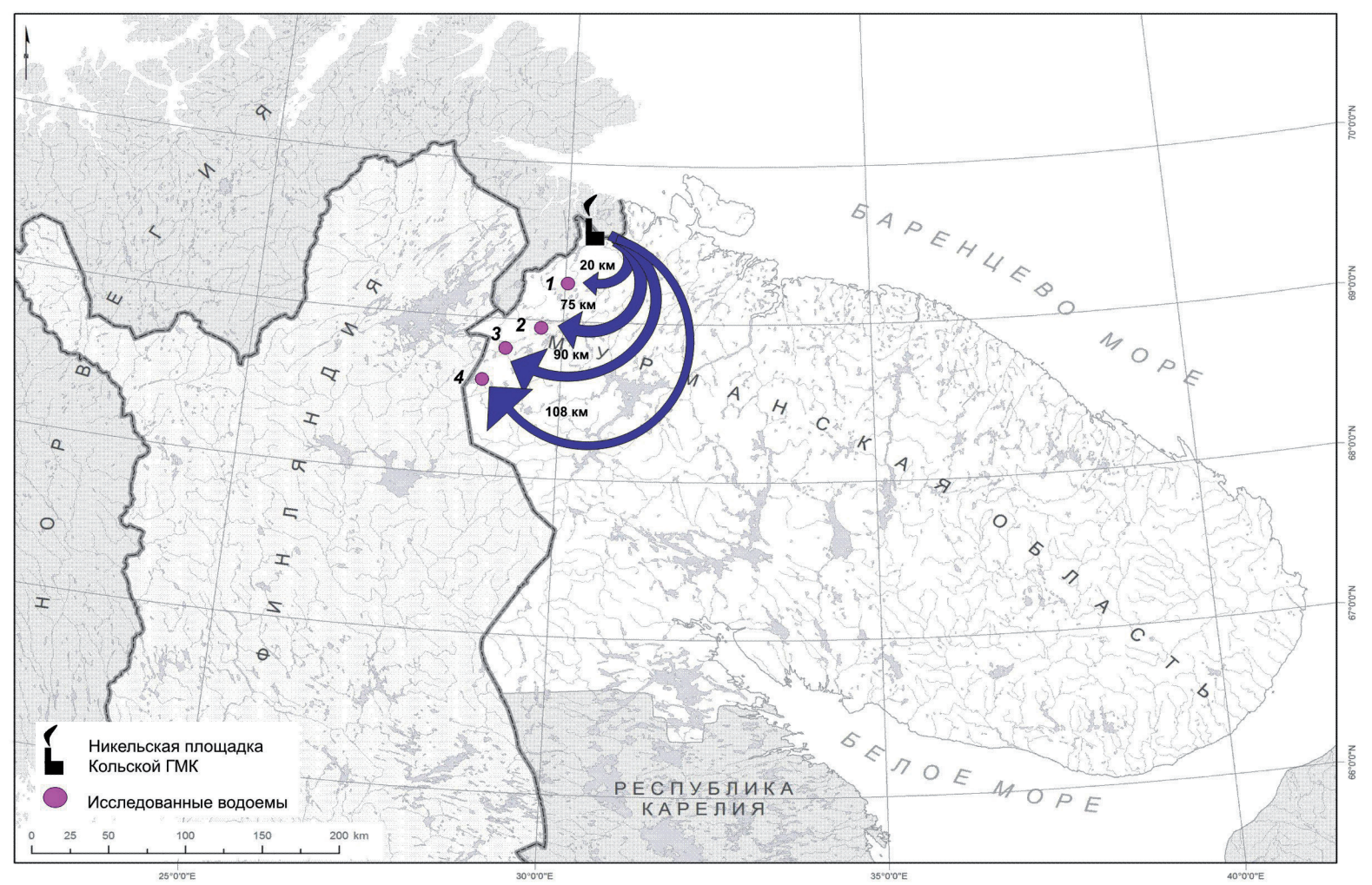

Рис. 1. Схема района исследований (1 - оз. Шуонияур; 2 - оз. Иля-Наутсиярви; 3 - оз. Виртуовошъяур; 4 - оз. Кочеяур). Стрелками обозначена удаленность водоема от источника загрязнения.

Fig. 1. Study area (1 - Shuoniyaur Lake ; 2 - Ilya-Nautsiyarvi Lake; 3 - Virtuovoshyaur Lake; 4 - Kocheyaur Lake). Arrows indicate the distance of the lake from the pollution source.

\section{Оз. Шуонияур}

Установлено, что нагрузка меди на водоем на основе данных о ее накоплении в рыбах (на примере гольца) за последнее десятилетие имеет тенденцию к увеличению (рис. 2). Неравномерность уровня антропогенной нагрузки на водоем отражает высокая вариабельность показателей накопления меди в организме. В печени и почках гольца её содержания изменялись от 6 до 500 мкг/г. Концентрации никеля в органах кумжи и гольца характеризовались наиболее высокими показателями у последнего (до 28 мкг/г). Для никеля, в отличие от меди, отмечается противоположная тенденция - снижение уровней его накопления у рыб за последние годы (рис. 2). Снижение содержания никеля в тканях рыб, вероятно, связано с более выраженным влиянием меди, определяющей аккумулирование других загрязняющих веществ в организме. Максимальные показатели накопления цинка были отмечены у кумжи в 2005 г. в почках (до 298 мкг/г) и жабрах (до 534 мкг/г). Достоверные отличия накопления металла между видами отмечены для жабр. В целом для цинка не отмечено до- 


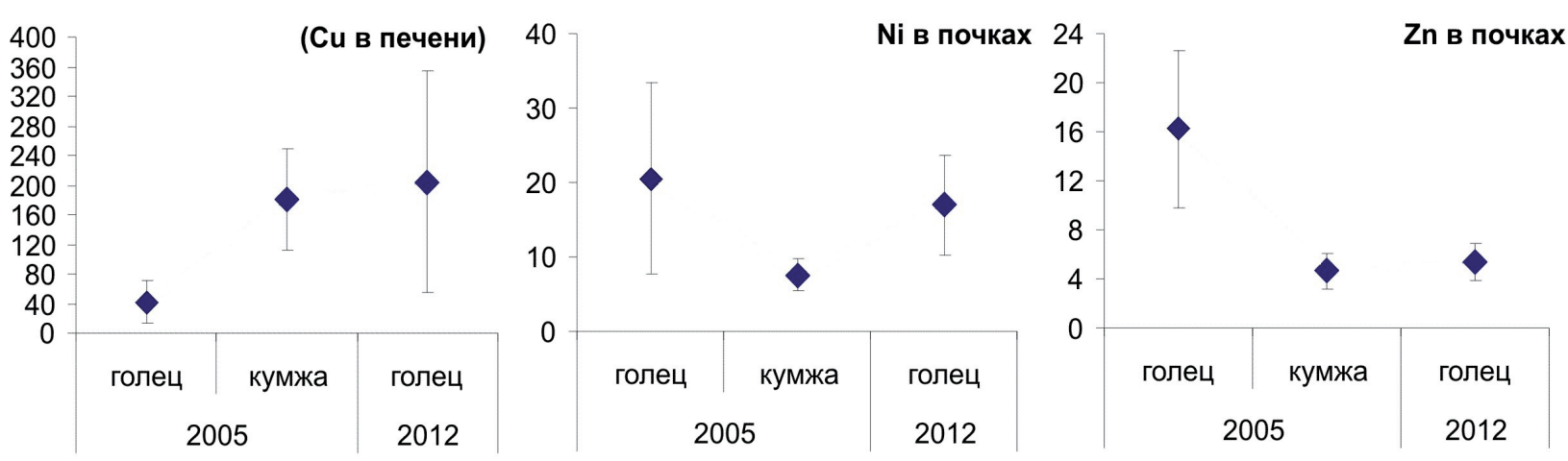

Рис. 2. Содержание тяжелых металлов в организмах рыб оз. Шуонияур (в мкг/г сух. веса).

Fig. 2. Heavy metals accumulation in fish of Shuoniyaur Lake (ppm).

стоверных временных закономерностей к увеличению или снижению его нагрузки на организмы рыб (рис. 2). Вероятно, вклад в поступление цинка от деятельности предприятий медно-никелевого производства в приграничном районе значительно ниже его поступлений связанных с глобальным загрязнением атмосферы.

\section{Оз. Иля-Наутсиярви}

Для данного водоема были проанализированы особенности накопления ТМ в органах сига, щуки и окуня. Медь в наиболее высоких концентрациях отмечалась в печени и почках рыб (преимущественно у сига). Средние содержания меди в печени рыб данного вида достигали 38, а в почках - 16.3 мкг/г (рис. 3). Более высокая нагрузка по организмы сига связана, вероятно, с особенностями их питания. Сиг, представленный в водоеме лишь малотычинковой формой, характеризуется бентосным типом питания. Содержание никеля характеризовалось максимальными содержаниями в почках рыб (рис. 3). Абсолютные максимальные показатели в почке отдельных особей сига достигали 7.3 мкг/г. В целом значительных межвидовых различий уровней накопления никеля между сигом и окунем не было выявлено. Содержание цинка практически во всех анализируемых органах было выше у щуки (рис. 3).

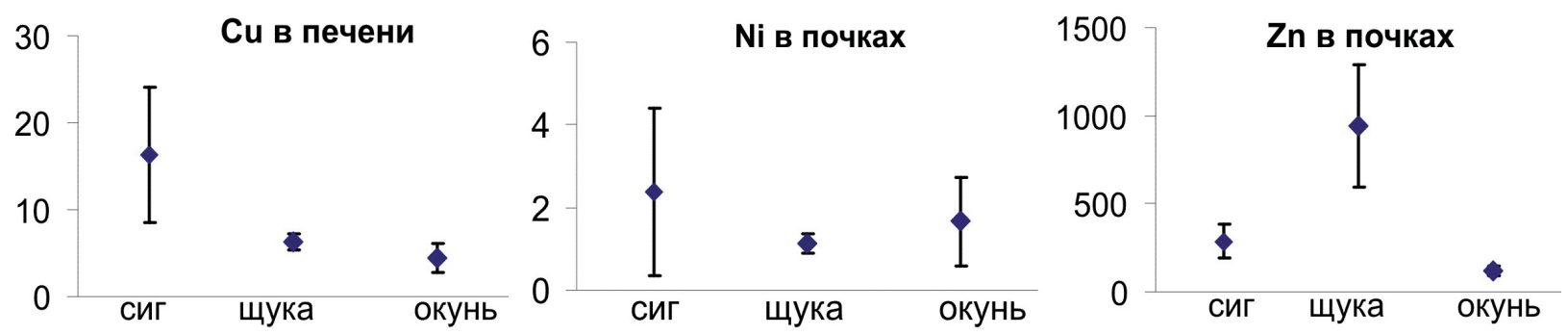

Рис. 3. Накопление тяжелых металлов в организмах рыб оз. Иля-Наутсиярви (в мкг/г сух. веса).

Fig. 3. Heavy metals accumulation in fish of Ilya-Nautsijarvi Lake (ppm).

\section{Оз. Виртуовошъяур}

Для данного водоема также были проанализированы уровни накопления ТМ в организмах сига щуки и окуня. Содержания меди в организмах исследованных рыб за весь период наблюдений не претерпели значительных изменений. Отмечено, что в печени и почках, где накопление меди происходит более интенсивно, концентрации металла были выше у сига (рис. 4). Причем для данного вида отмечена устойчивая тенденция к увеличению содержания меди в печени на протяжении последнего десятилетия. Это может свидетельствовать о сохраняющемся уровне нагрузки меди на водоемы приграничного района, как за счет процессов аэротехногенного переноса, так и поступления с территорий водосборных бассейнов и донных отложений. Наиболее высокие содержания 
меди в печени отдельных особей сига были отмечены в 2013 г. (174 мкг/г), в почках - до 165 мкг/г в 2005 г. Межвидовые различия также были статистически достоверны по содержанию меди в печени и почках сига по отношению к аналогичным показателям окуня и щуки. Никель, содержания которого были наиболее высоки в почках рассматриваемых рыб, имеет тенденцию к снижению уровней накопления у всех рассматриваемых видов. В целом, это характерно и для других органов и тканей сига, окуня и щуки. Межвидовые особенности концентрирования никеля, за исключением мышечной ткани, показали, что содержания металла было выше в организмах сига (рис. 4). Межвидовые различия статистически не были подтверждены. В целом концентрации цинка в организмах рыб на протяжении последнего десятилетия остаются на прежнем уровне. Наиболее высокие содержания металла отмечались в почках и жабрах рыб (рис. 4).

оз. Виртуовошъяур
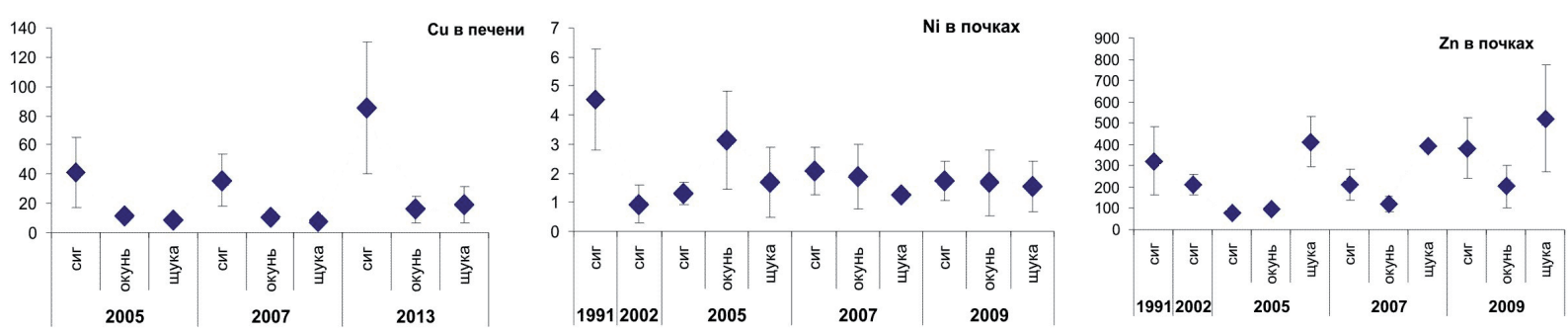

оз. Кочеяур
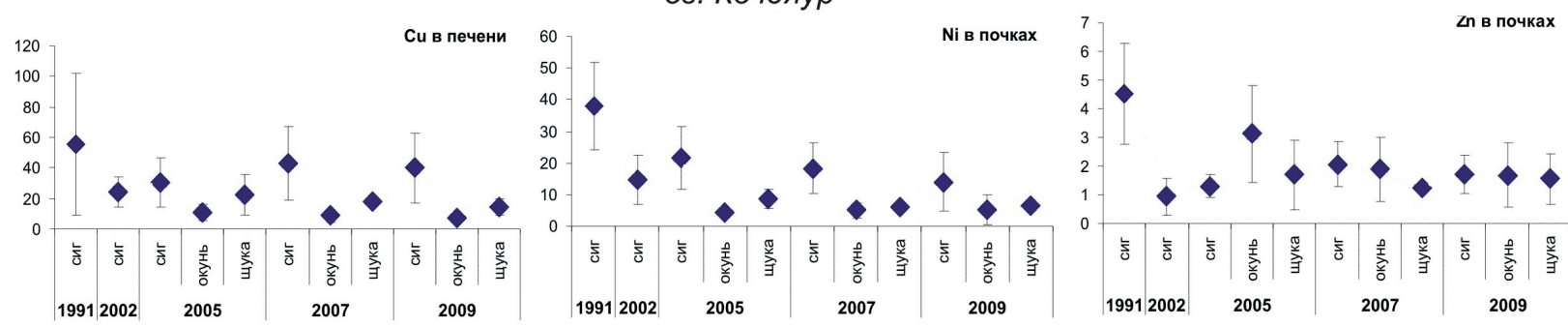

Рис. 4. Накопление тяжелых металлов в организмах рыб оз. Виртуовошъяур и Кочеяур (в мкг/г сух. веса).

Fig. 4. Heavy metals accumulation in fish of Virtuovoshyaur and Kocheyaur Lake (ppm).

\section{Оз. Кочеяур}

Установлено, что уровни накопления меди в печени были выше по сравнению с другими органами и достигали значительных величии, сопоставимых с уровнями у рыб вблизи предприятия Кольская ГМК. Также показано, что нагрузка меди на организмы рыб имеет постоянный характер на протяжении последних лет и практически не снижается по сравнению с данными начала 1990-х гг. (рис. 4). Как и для ранее рассматриваемых водоемов, наиболее интенсивно медь накапливается в организмах сига, характеризующегося бентосным типом питания. Максимальные средние содержания меди в печени у рыб в современных условиях достигают 40-44 мкг/г (сиг), 14-19 мкг/г (щука). В накоплении никеля в организмах исследованных рыб были отмечены некоторые общие закономерности, характерные и для меди. Содержания никеля во всех анализируемых органах сига было выше в период начала 1990-х гг. по сравнению с современными показателями (рис. 4). Органамимишенями для никеля являются почки и жабры рыб. Средние концентрации никеля в почках органах достигали 1.7-5 (сиг), 1.7-3.1 (окунь), 1.3-1.7 мкг/г (щука). В жабрах аналогичные показатели варьировали в следующих пределах 0.7-2.6 (сиг), 1.8-2.6 (окунь), 3.5-3.7 мкг/г (щука). Для данного элемента не было выявлено характерных видовых закономерностей концентрирования в органах и тканях рыб. Тем не менее, наиболее высокие содержания никеля чаще отмечались в организмах сига. Необходимо отметить, что уровень антропогенной нагрузки на водоем остается на доста- 
точно высоком уровне и значительного сокращения содержаний ТМ в организмах рыб не происходит. Уровни антропогенной нагрузки цинка на организмы рыб данного водоема сопоставимы с аналогичными показателями оз. Виртуовошъяур. Здесь концентрации цинка достигают наиболее высоких значений в печени, почках и жабрах сига и щуки. У отдельных особей концентрации цинка превышали 1000 мкг/г (сиг - печень; щука - почки). Средние содержания цинка в печени и почках у разных видов варьировали от 70 до 500 мкг/г.

Анализ многолетних данных по накоплению ТМ в организмах рыб ряда озер Евро-Арктической зоны РФ позволяет сделать вывод о том, что уровни антропогенной нагрузки на водоемы на протяжении последних десятилетий остаются на прежнем уровне, а по ряду элементов характеризуются ее ростом. Отмечено, что приоритетные загрязняющие вещества региона - никель и медь, а также цинк в более высоких концентрациях содержатся в тканях сига. Практически во всех рассматриваемых водоемах зарегистрирована высокая вариабельность содержаний ТМ в пределах одного вида. В ходе исследований также установлено, что интенсивность антропогенной нагрузки на исследованные водоемы не зависит от их удаленности относительно локального источника загрязнения и определяется множеством факторов. К их числу можно отнести процессы глобального загрязнения атмосферы, ландшафтные особенности территории, геологическое строение слагающих пород и характер растительности на водосборе, морфометрию водоемов, проточность озер, предрасположенность к процессам закисления вод и др.

Работа выполнена в рамках тем НИР №9-12-2213, №0226-2015-0001 и гранта РФФИ (№ 1805-60125).

\section{Литература}

1. Даувальтер В.А., Кашулин Н.А. Оценка экологического состояния Арктической пресноводной системы по результатам исследований содержания тяжелых металлов в донных отложениях // Геохимия. 2018. № 8. C. 805-819.

2. Терентьев П.М., Кашулин Н.А. Изучение пространственно-временных особенностей накопления некоторых тяжелых металлов в организмах сига водоемов Северной Фенноскандии // Вестник КНЦ РАН. 2010. № 1. C. 57-62.

3. Boquete M., Aboal J., Carballeira A., Fernandez J. Effect of age on the heavy metal concentration in segments of Pseudoscleropodium purum and the biomonitoring of atmospheric deposition of metals // Atmos. Environ. 2014. 86. P. $28-34$.

4. Dauvalter, V.A., Kashulin, N.A. Mercury Pollution of Lake Imandra Sediments, the Murmansk Region, Russia // International Journal of Environmental Research. 2018. V.12 (6). P. 939-953.

5. Fu J., Zhao C., Luo Y., Liu C., Kyzas G.Z., Luo Y., Zhao D., An S., Zhu H. Heavy metals in surface sediments of the Jialu River, China: Their relations to environmental factors // J. Hazard. Mater. 2014. 270. P. 102-109.

6. Hansen J.A., Welsh P.G., Lipton J., Suedkamp M.J. The effects of long-term cadmium exposure on the growth and survival of juvenile bull trout (Salvelinus confluentus) // Aquatic Toxicology. V. 58. 2002. P. 165-174.

7. Kashulin N. A., Terentyev P. M., Amundsen P.-A., Dauvalter V. A., Sandimirov S. S., Kashulin A. N. Specific features of accumulation of $\mathrm{Cu}, \mathrm{Ni}, \mathrm{Zn}, \mathrm{Cd}$, and $\mathrm{Hg}$ in two whitefish Coregonus lavaretus (L.) morphs inhabiting the Inari-Pasvik lacustrine-riverine system // Inland water biology. 2011. V. 4. №3. P. 383-392. 